\title{
Efektivitas Minuman Kacang Hijau terhadap Peningkatan Kadar Hemoglobin Remaja Putri di Panti Asuhan di Kota Pekanbaru
}

\author{
Fachriani Putri $^{1^{*}}$, Riza Iriani Nasution ${ }^{2}$
}

\begin{abstract}
The complete mung bean's phytochemicals composition help the hematopoiesis process increasing hemoglobin levels. Hemoglobin level is important as anemia sign. Anemia in adolescent girls might affect reproductive health. The aim of this study was to determine the effectiveness of mung beans compote to increase hemoglobin levels for adolescent girls at the Pekanbaru City Orphanage. This study was quasi-experimental study with one group pre test-post test design method. This study included 28 adolescent girls who had experienced menses and were not under any other medications. We used purposive sampling method to chose the subject. Hemoglobin levels were assessed pre and post oral administration of a cup mung bean compote 2 times a day for a week, each volume of $250 \mathrm{ml}$. The results were analyzed by paired t-test. We found that the average hemoglobin levels of adolescent girls are $13.13 \mathrm{~g} \%$ and $13.14 \mathrm{~g} \%$ respectively for pre and post treatment. Statistically, there was unsignificant effect of mung beans compote in increasing hemoglobin level $(\mathrm{p}=0.97$.
\end{abstract}

Keywords: adolescent girls, anemia, hemoglobin levels, mung bean compote

Anemia merupakan salah satu masalah kesehatan di dunia terutama di negara berkembang. Anemia banyak diderita oleh remaja putri dan ibu hamil. Menurut World Health Organization (WHO) tahun 2013, prevalensi anemia pada remaja putri masih cukup tinggi, antara 40-88\% sedangkan menurut Survei Kesehatan Rumah Tangga (SKRT) tahun 2012 sebesar 57,1\%. ${ }^{1,2}$ Data penelitian dari berbagai daerah di Indonesia menunjukkan kisaran antara $32,4-61 \% .^{3}$

Data dari Dinas Kesehatan Provinsi Riau tahun 2014 menunjukkan kejadian anemia pada remaja putri masih tinggi yaitu 57,8\%, sedangkan data dari Dinas Kesehatan Kota Pekanbaru belum ada. Namun dari hasil penelitian Handayani dkk tahun 2014 yang meneliti hubungan status gizi dengan kejadian anemia pada remaja putri di SMA Negeri 8 Pekanbaru, menemukan 35 siswi (41\%) yang anemia dari 86 siswi yang diteliti. ${ }^{4}$

\footnotetext{
* Korespondensi penulis : fachriani_p@yahoo.co.id

1 KJFD Ilmu Kesehatan Masyarakat Fakultas Kedokteran Universitas Riau

2 KJFD Ilmu Kesehatan Anak Fakultas Kedokteran Universitas Riau/ RSUD Arifin Achmad Provinsi Riau
}

Anemia adalah suatu keadaan dengan jumlah massa eritrosit (red cell mass) menurun yang ditunjukkan dengan penurunan kadar hemoglobin, hematokrit dan hitung eritrosit (red cell count). ${ }^{5}$ Seseorang dikatakan anemia jika kadar $\mathrm{Hb}<12$ gr/ d1. ${ }^{6}$ Salah satu penyebab anemia adalah kekurangan zat gizi seperti zat besi, asam folat dan vitamin B12 yang diperlukan untuk proses eritropoesis. Oleh karena itu anemia kekurangan zat gizi disebut juga anemia gizi. Tapi karena penyebab kekurangan zat gizi yang paling sering adalah zat besi, maka anemia gizi disebut juga anemia gizi besi. ${ }^{7,8}$ Anemia gizi besi menjadi salah satu fokus perbaikan gizi masyarakat selain defisiensi vitamin A dan Gangguan Akibat Kekurangan Iodium (GAKI) .

Salah satu faktor yang mempengaruhi kejadian anemia adalah usia remaja. Baik remaja putri maupun remaja putra. Percepatan pertumbuhan pada usia remaja (growth spurt) membutuhkan energi, protein dan zat besi lebih banyak dibandingkan kelompok umur lainnya. Kebutuhan zat besi remaja putri lebih banyak lagi dibandingkan remaja putra, karena remaja putri mengalami menstruasi tiap bulan yang menyebabkannya banyak kehilangan zat besi. ${ }^{10,11}$ Selain itu, remaja putri juga sangat memperhatikan 
bentuk tubuhnya, sehingga banyak membatasi konsumsi makanan ataupun melakukan pantangan makanan. ${ }^{12}$

Remaja putri yang tinggal di panti asuhan rentan terhadap kekurangan gizi. Karena tidak semua panti asuhan memiliki donatur tetap tiap bulan untuk memenuhi biaya operasional panti. Menurut Faridah dalam Gunatmaningsih, pendapatan dapat mempengaruhi perubahan konsumsi pangan keluarga. Penurunan pendapatan akan menyebabkan penurunan kualitas dan kuantitas pangan yang dibeli, yang dapat mengakibatkan tidak terpenuhinya kebutuhan zat gizi, salah satunya zat besi sehingga dapat berdampak terhadap timbulnya anemia. ${ }^{13}$

Kurangnya konsumsi makanan yang mengandung zat besi, atau konsumsi makanannya cukup zat besi tapi bioavailabilitas zat besi dari makanan yang dikonsumsinya rendah juga membuat jumlah zat besi yang diserap oleh tubuh kurang. ${ }^{14}$ Kekurangan zat besi merupakan penyebab utama terjadinya anemia gizi. Untuk mencegahnya diperlukan asupan zat besi dari makanan yang mengandung banyak zat besi seperti daging, hati, ikan, susu, yoghurt, sayuran berwarna hijau dan kacang-kacangan. ${ }^{8,15}$

Salah satu kacang-kacangan yang kandungan zat besinya tinggi adalah kacang hijau (vigna radiata). ${ }^{15}$ Jumlah kandungan zat besinya $6,7 \mathrm{mg}$ per 100 gram. ${ }^{16,17}$ Penyajian kacang hijau yang paling efektif dalam bentuk sari kacang hijau. Mengonsumsi dua gelas kacang hijau setiap hari sama dengan mengonsumsi $50 \%$ kebutuhan zat besi setiap hari yaitu $18 \mathrm{mg}$ per-hari. ${ }^{18,19}$

Hasil penelitian Amalia tahun 2016 tentang efektifitas minuman kacang hijau terhadap peningkatan kadar $\mathrm{Hb}$ pada 38 mahasiswi semester 4 prodi D-III Kebidanan STIKES Muhammadiyah Lamongan, menemukan pengaruh pemberian minuman kacang hijau terhadap peningkatan kadar hemoglobin sebesar $1 \mathrm{~g} \%$ dari $9,6 \mathrm{~g} \%$ menjadi 10.6 $\mathrm{g} \%$ dengan nilai $\mathrm{p}=0,000 .{ }^{18}$ Demikian pula hasil penelitian Faridah dan Indraswari tahun 2016 tentang pemberian kacang hijau sebagai upaya peningkatan kadar hemoglobin pada remaja putri anemia di kelas X SMK Al - Islam Kudus, menemukan pengaruh kacang hijau terhadap peningkatan kadar $\mathrm{Hb}$ sebesar $0,53 \mathrm{~g} \%$ dengan nilai $\mathrm{p}=0,005$. $^{19}$
Menurut Permenkes Nomor 37 Tahun 2012 tentang penyelenggaraan laboratorium pusat kesehatan masyarakat, diagnosis anemia ditegakkan melalui pemeriksaaan laboratorium dengan menentukan kadar $\mathrm{Hb}$ dalam darah. Remaja Putri (Rematri) dan Wanita Usia Subur (WUS) dikatakan menderita anemia bila kadar hemoglobin dalam darahnya kurang dari $12 \mathrm{~g} / \mathrm{dL}^{9}{ }^{9}$

\section{METODE}

Penelitian ini adalah penelitian kuasi eksperimental dengan rancangan one group pre testpost test design. Populasi dalam penelitian ini adalah seluruh remaja putri berusia antara 11-22 tahun yang diasuh oleh panti asuhan sebanyak 35 orang. Sampel dalam penelitian ini adalah remaja putri yang sudah menstruasi dan tidak sedang dalam pengobatan yaitu sebanyak 28 orang yang diambil secara purposive sampling.

Data umur dan tingkat pendidikan diperoleh melalui kuesioner. Sedangkan data kadar hemoglobin diperoleh melalui pengukuran hemoglobin sebelum dan sesudah intervensi. Pengukuran dilakukan dengan mengambil darah vena remaja putri sebanyak $2 \mathrm{ml}$ oleh petugas dari UPT Laboratorium Kesehatan dan Lingkungan Dinas Kesehatan Provinsi Riau. Selanjutnya diperiksa dengan menggunakan alat Micros 60 dengan metode Automatic.

Intervensi dilakukan dengan memberikan minuman kacang hijau 2 kali sehari, pagi dan sore masing-masing sebanyak 1 gelas ukuran $250 \mathrm{ml}$, setiap hari selama 1 minggu. Selanjutnya data dianalisis secara univariat dan bivariat. Untuk mengetahui perbedaan kadar hemoglobin sebelum dan sesudah pemberian minuman kacang hijau, dilakukan dengan uji statistik parametrik uji tberpasangan $(\mathrm{p}<0.05)$, dengan interval kepercayaan $95 \%(a ́=0.05)$.

\section{HASIL}

Distribusi umur remaja putri dapat dilihat pada tabel 1. Rerata umur remaja putri adalah 16 tahun dengan umur paling rendah 11 tahun dan paling tinggi 22 tahun. 
Tabel 1. Distribusi Umur Remaja Putri

\begin{tabular}{ccccccc}
\hline & Mean & Median & SD & Min & Max & CI \\
\hline $\begin{array}{c}\text { Umur } \\
\text { Remaja putri }\end{array}$ & 16 & 16 & 2,91 & 11 & 22 & $14,90-17,10$ \\
\hline
\end{tabular}

Distribusi frekuensi pendidikan remaja putri dapat dilihat pada tabel 2. Tingkat pendidikan remaja putri mulai dari SD sampai dengan Perguruan Tinggi.
Tingkat pendidikan remaja putri paling banyak dijumpai pada tingkat SMA/MA yaitu 12 orang $(42,85 \%)$.

Tabel 2. Distribusi Frekuensi Pendidikan Remaja Putri

\begin{tabular}{cccc}
\hline No & Pendidikan & Jumlah & $(\%)$ \\
\hline 1 & SD/MI & 5 & $17,85 \%$ \\
2 & SMP/MTs & 7 & $25 \%$ \\
3 & SMA/MA & 12 & $42,85 \%$ \\
4 & PT & 4 & $14,28 \%$ \\
& Jumlah & 28 & $100 \%$ \\
\hline
\end{tabular}

Distribusi kadar hemoglobin remaja putri sebelum dan sesudah pemberian minuman kacang hijau dapat dilihat pada tabel 3. Rerata kadar hemoglobin remaja putri sebelum pemberian 13,13 $\mathrm{g} \%$ dengan kadar hemoglobin paling rendah 11,60 g\% dan paling tinggi $14,50 \mathrm{~g} \%$. Sedangkan rerata kadar hemoglobin remaja putri sesudah pemberian 13,14 g\% dengan kadar hemoglobin paling rendah $11,90 \mathrm{~g} \%$ dan paling tinggi $14,80 \mathrm{~g} \%$

Tabel 3. Distribusi Kadar Hemoglobin Remaja Putri Sebelum dan Sesudah Pemberian Minuman Kacang Hijau

\begin{tabular}{ccccccc}
\hline & Mean & Median & SD & Min & Max & CI \\
\hline $\begin{array}{c}\text { Kadar } \\
\text { hemoglobin } \\
\text { sebelum } \\
\text { pemberian }\end{array}$ & 13,13 & 13,30 & 0,86 & 11,60 & 14,50 & $12,79-13,46$ \\
\hline $\begin{array}{c}\text { Kadar } \\
\text { hemoglobin } \\
\text { sesudah } \\
\text { pemberian }\end{array}$ & 13,14 & 13,05 & 0,83 & 11,90 & 14,80 & $12,82-13,46$ \\
\hline
\end{tabular}

Perbedaan rerata kadar hemoglobin remaja putri sebelum dan sesudah pemberian minuman kacang hijau dapat dilihat pada tabel 4. Dari hasil uji statistik paired sample t-test diperoleh beda kadar hemoglobin sebelum dan sesudah pemberian minuman kacang hijau sebesar 0,004 dengan nilai $\mathrm{p}$ 0,97 . Hal ini berarti tidak terdapat pengaruh pemberian minuman kacang hijau terhadap peningkatan kadar hemoglobin remaja putri sebelum dan sesudah pemberian minuman kacang hijau. 
Tabel 4. Perbedaan Rerata Kadar Hemoglobin Remaja Putri Sebelum dan Sesudah Pemberian Minuman Kacang Hijau

\begin{tabular}{cccccc}
\hline & N & Mean & SD & Mean Diff & P value \\
\hline Post test & 28 & 13,14 & 0,83 & 0,004 & 0,97 \\
\hline Pre test & 28 & 13,13 & 0,86 & & \\
\hline
\end{tabular}

\section{PEMBAHASAN}

Tabel 1 menunjukkan umur remaja putri berkisar antara 11 sampai dengan 22 tahun, dengan rerata 16 tahun. Menurut WHO, seseorang disebut remaja apabila berusia antara 10-19 tahun. ${ }^{20}$ Data Riskesdas (2013) menunjukkan kelompok umur antara 5-14 tahun yang menderita anemia sebesar $26,4 \% .^{21}$

Salah satu faktor yang mempengaruhi kejadian anemia adalah usia karena pada usia remaja terjadi percepatan pertumbuhan (growth spurt) yang membutuhkan banyak asupan zat besi. Kebutuhan zat besi remaja putri lebih banyak lagi dibandingkan remaja putra, karena remaja putri mengalami menstruasi setiap bulan yang menyebabkannya kehilangan zat besi $0,8 \mathrm{mg} /$ hari selama menstruasi. ${ }^{10,11}$

Tabel 3 menunjukkan kadar hemoglobin remaja putri sebelum pemberian minuman kacang hijau berkisar dari $11,6 \mathrm{~g} \%$ sampai dengan $14,5 \mathrm{~g} \%$ dengan rerata $13,13 \mathrm{~g} \%$. Sedangkan sesudah pemberian minuman kacang hijau berkisar dari $11,9 \mathrm{~g} \%$ sampai dengan $14,8 \mathrm{~g} \%$ dengan rerata $13,14 \mathrm{~g} \%$.

Hemoglobin adalah molekul berbentuk bulat yang merupakan kompleks protein, yang tersusun dari protein globin dan heme. Heme adalah turunan porfirin yang mengandung zat besi $(\mathrm{Fe})$. Tiap gram hemoglobin mengangkut $1,34 \mathrm{ml}$ oksigen. Hemoglobin dan oksigen membentuk oksihemoglobin di paru-paru. Proses oksihemoglobin membutuhkan zat besi. Oleh karena itu zat besi penting dalam pembentukan hemoglobin, mioglobin, dan substansi lainnya seperti sitokrom, sitokrom oksidase, peroksidase, dan katalase. 1,19,22,23

Salah satu cara meningkatkan kadar hemoglobin dalam darah adalah dengan meningkatkan konsumsi makanan yang banyak mengandung zat besi, baik dari bahan makanan hewani ( daging, ikan, ayam, hati, telur) maupun bahan makanan nabati (sayuran berwarna hijau tua, kacang-kacangan, tempe). Disertai buah-buahan yang banyak mengandung vitamin $\mathrm{C}$ (tomat, jeruk, nanas) untuk meningkatkan penyerapan zat besi di dalam usus. ${ }^{24}$

Bahan makanan nabati (kacang-kacangan) yang kandungan fitokimianya sangat lengkap dan dapat membantu proses hematopoiesis adalah kacang hijau. Kandungan zat besi di dalam kacang hijau $6,7 \mathrm{mg} / 100 \cdot{ }^{16,17}$ Setengah cangkir kacang hijau mengandung 90 gram air, $127 \mathrm{kcal}$ energi, 11 gram protein, 10 gram karbohidrat, 4 gram serat, 6 gram lemak, $131 \mathrm{mg}$ kalsium, 2,25 mg besi, $54 \mathrm{mg}$ magnesium, $485 \mathrm{mg}$ potasium, $13 \mathrm{mg}$ sodium, 0,82 mg zinc, 7 mikrogram vitamin A, $0,23 \mathrm{mg}$ tiamin, $0,14 \mathrm{mg}$ riboflavin, $1,13 \mathrm{mg}$ niasin, $0,05 \mathrm{mg}$ vitamin B6, 100 mikrogram folat, $15 \mathrm{mg}$ vitamin $\mathrm{C}$ dan 1 mikrogram selenium. ${ }^{15,25}$ Mengonsumsi dua cangkir kacang hijau setiap hari sama dengan mengonsumsi $83,6 \%$ vitamin B1 (tiamin), 51\% vitamin B2 (riboflavin), dan 32,3\% niasin dari kebutuhan normal setiap hari. ${ }^{19}$

Secara statistik hasil penelitian ini tidak menemukan pengaruh pemberian minuman kacang hijau terhadap peningkatan kadar hemoglobin remaja putri di Panti Asuhan. Rerata kadar hemoglobin remaja putri sebelum pemberian minuman kacang hijau 13,13 g\% (tidak anemia) dan sesudah pemberian $13,14 \mathrm{~g} \%$ (tidak anemia) dengan $\mathrm{p}$ value 0,97 .

Hasil penelitian Adhisti tahun 2011 yang meneliti hubungan status antropometri dan asupan gizi dengan kadar $\mathrm{Hb}$ dan ferritin remaja putri pondok pesantren At-Taqwa Semarang juga tidak menemukan hubungan yang bermakna antara asupan zat besi dengan kadar $\mathrm{Hb}(\mathrm{p}=0,446) .{ }^{26}$ Demikian pula hasil penelitian Gunatmaningsih tahun 2007 yang meneliti faktor-faktor yang berhubungan dengan kejadian anemia pada remaja putri di SMA Negeri 1 Kecamatan Jatibarang Kabupaten Brebes, tidak menemukan hubungan yang bermakna antara konsumsi zat besi dengan kejadian anemia $(\mathrm{p}=$ $0,592) \cdot{ }^{13}$ 
Asupan gizi terutama zat besi mempunyai peranan penting dalam pembentukan hemoglobin. Namun asupan zat besi kurang dari Angka Kecukupan Gizi (AKG) tidak langsung mempengaruhi kadar $\mathrm{Hb}$ karena tubuh masih memiliki cadangan zat besi di hepar. Setelah cadangan besi di hepar habis, baru akan menyebabkan penurunan kadar Hb. ${ }^{13,26}$

Selain itu, panti asuhan tempat dilakukannya penelitian ini berada ditengah kota dan banyak menerima sumbangan makanan setiap hari, sehingga konsumsi makanan remaja putri di panti asuhan ini tergolong baik. Faktor lain yang berkontribusi terhadap kejadian anemia adalah konsumsi makanan. Apabila makanan yang dikonsumsi beraneka ragam maka penyerapan zat besi di dalam tubuh akan meningkat sehingga kejadian anemia dapat dicegah. ${ }^{27}$

Penelitian Kirana tahun 2011, yang meneliti hubungan antara asupan zat gizi (protein, vitamin A, vitamin $C$, dan zat besi) dengan kejadian anemia pada remaja putri di SMA Negeri 2 Semarang, menemukan hubungan antara asupan zat gizi dengan kejadian anemia. Makin tinggi asupan protein, vitamin $A$, vitamin $C$, dan zat besi maka makin tinggi nilai kadar hemoglobin sehingga kejadian anemia dapat dicegah. ${ }^{27}$

\section{SIMPULAN}

Tidak terdapat pengaruh pemberian minuman kacang hijau terhadap peningkatan kadar hemoglobin $(\mathrm{p}=0,97)$ remaja putri di Panti Asuhan di Kota Pekanbaru sebelum dan sesudah diberikan minuman kacang hijau 2 kali sehari, pagi dan sore masingmasing sebanyak 1 gelas ukuran $250 \mathrm{ml}$, setiap hari selama 1 minggu.

\section{DAFTAR PUSTAKA}

1. WHO. Worldwide prevalence of anemia 19932005: WHO Global database on anemia; 2008.

2. Kementerian Kesehatan RI. Profil kesehatan Indonesia; 2013.

3. Basith A, Agustina R, Dian N. Faktor-faktor yang berhubungan dengan kejadian anemia pada remaja putri. Dunia Keperawatan. 2017;5(1):110.
4. Handayani WP, Novayelinda R, Jumaini. Hubungan status gizi dengan kejadian anemia pada remaja putri. JOM. 2014;2(1): 742-9

5. Gallagher ML. The nutrients and their metabolism. In: Mahanan LK, Escott-Stump S. Krause food, nutrition, and diet therapy. Philadelphia: Saunders; 2008

6. Proverawati dan Asfuah. Buku ajar gizi untuk kebidanan. Yogyakarta:Nuha Medika, 2009

7. Fatmah. Gizi dan kesehatan masyarakat : Anemia. Jakarta : PT. Raja Grafindo Persada; 2011

8. Arisman, M. Buku Ajar Ilmu Gizi dalam Daur Kehidupan. Jakarta: Penerbit Buku Kedokteran. EGC; 2009

9. Kementerian Kesehatan RI. Direktorat Gizi Masyarakat. Pedoman pencegahan dan penanggulangan anemia pada remaja putri dan wanita usia subur (WUS); 2016

10. Sandjaja S. Prevalensi dan faktor risiko anemia pada wanita usia subur di rumah tangga miskin di Kabupaten Tasikmalaya dan Ciamis, Provinsi Jawa Barat. Jurnal Kesehatan Reproduksi. 2016;7(No.2):71-82

11. Indartanti D, Kartini A. Hubungan status gizi dengan kejadian anemia pada remaja putri. Journal of Nutrition College. 2014;3(2).

12. Sarlitowirawan. Psikologi remaja (Ed.Revisi). Jakarta : PT.Rajagrafindo Persada; 2006

13.Gunatmaningsih D. Faktor-faktor yang berhubungan dengan kejadian anemia pada remaja putri di SMA Negeri 1 Kecamatan Jatibarang Kabupaten Brebes Tahun 2007. [Skripsi]. Semarang: Fakultas Ilmu Keolahragaan Jurusan Ilmu Kesehatan Masyarakat UNS; 2007

14.Permaesih D, Herman S. Faktor-faktor yang mempengaruhi anemia pada remaja. Bul Panel Kesehat. 2005;33(4):161-71.

15. Astawan, M. Sehat dengan hidangan kacang dan biji - bijian. Depok: Penebaran Swadaya; 2009

16. Wirakusumah. Jus buah dan sayuran untuk menjaga kesehatan dan kebugaran anda. Jakarta : Penebar Plus; 2007 
17. Rukmana. Ubi jalar - budidaya dan pasca panen. Penerbit Kanisius. Yogyakarta; 1997

18. Amalia A. Efektifitas minuman kacang hijau terhadap peningkatan kadar Hb. Artikel RAKERNAS AIPKEMA 2016 "Temu ilmiah hasil penelitian dan pengabdian masyarakat"; $2016: 13-18$

19. Faridah U, Indraswari V. Pemberian kacang hijau sebagai upaya peningkatan kadar hemoglobin pada remaja putri. 5th Urecol Proceeding. 2017;(February):215-22.

20.Infodatin Reproduksi Remaja. Pusat Data dan Informasi Kementerian Kesehatan RI; 2017

21.Riset Kesehatan Dasar. Badan Penelitian dan Pengembangan Kesehatan, Kementerian Kesehatan RI; 2013

22.Pratiwi E. Faktor-faktor yang mempengaruhi anemia pada siswi MTS Ciwandan CilegonBanten Tahun 2015. [Skripsi]. Program Studi Kesehatan Masyarakat Fakultas Ilmu Kesehatan dan Kedokteran UIN Syarif Hidayatullah; 2016
23. Martini. Faktor - faktor yang berhubungan dengan kejadian anemia pada remaja putri di MAN 1 Metro. Jurnal Kesehatan Metro Sai Wawai. 2015;7(1): 1-7.

24.Almaitzer, S. Prinsip dasar ilmu gizi. Jakarta: Gramedia Pustaka Utama; 2011

25. Syatriani S, Aryani A. Konsumsi makanan dan kejadian anemia pada siswi salah satu SMP di Kota Makassar. Jurnal Kesehatan Masyarakat Nasional 2010;4(6): 251-4.

26. Adhisti AP. Hubungan status antropometri dan asupan gizi dengan kadar $\mathrm{Hb}$ dan ferritin remaja putri (Penelitian pada remaja putri Pondok Pesantren At-Taqwa Semarang). Karya tulis Ilmiah. Semarang : Fakultas Kedokteran Universitas Diponegoro; 2011.

27. Kirana DP. Hubungan asupan zat gizi dan pola menstruasi dengan kejadian anemia pada remaja putri di SMAN 2 Semarang. [Thesis]. Program Studi Ilmu Gizi Fakultas Kedokteran Universitas Diponegoro; 2011. 